\title{
ANALYSIS OF RELATIONSHIPS OF EMOTIONAL BURN OUT FEATURES AND INDICATORS OF EMOTIONAL INTELLIGENCE AMONG MEDICAL WORKERS
}

\author{
N. Pylypenko, 0. Sydorenko
}

State Institution of Science «Research and Practical Center of Preventive and Clinical Medicine» State Administrative Department, Kyiv, Ukraine

\section{Symmary}

Purpose - the aim of this article is to present the results of a statistical analysis of the relationship between the features of emotional burnout and indicators of emotional intelligence among medical workers.

Material and methods -4 groups of respondents (110 medical workers) took part in the study: surgical doctors, therapeutic doctors, surgical nurses, therapeutic nurses. Evaluation of the features of emotional burnout and emotional intelligence was carried out using diagnostic methods of emotional burnout (V. Boyko), the questionnaire of emotional burnout by K. Maslach and S. Jackson (adaptation by N. Vodopyanova) and the method of emotional intelligence (N. Hall).

The study consisted of two stages. The purpose of the first stage was to determine the level and characteristics of the manifestation of emotional burnout of medical workers according to the following symptoms: (emotional exhaustion; depersonalization; reduction of personal achievements; «stress» (experiencing traumatic circumstances, dissatisfaction with oneself, caged, anxiety and depression); «resistance» (inadequate selective emotional response, emotional and moral disorientation, expansion of the sphere of saving emotions, reduction of professional duties); «exhaustion» (emotional deficit, emotional detachment, psychosomatic and psychovegetative disorders). The level of manifestation of emotional intelligence of medical workers was also assessed according to the following indicators: emotional awareness, emotion management, self-motivation, empathy, recognition of other people's emotions The second stage of the study was aimed at determining the characteristics of the relationship of individual indicators of emotional benefit screaming with specific indicators of the emotional intelligence of health care workers. Mathematical processing of the research results was carried out using Spearman's correlation coefficient by means of the SPSS 17 computer program.

Results and discussion. The results of our research have shown that: 1) the overwhelming majority of the test subjects have high and medium levels of reduction of personal achievements, and such a phase of emotional burnout as resistance» (inadequate selective emotional response, emotional and moral disorientation, expansion of the sphere of economy of emotions, reduction of professional duties); 2) half of respondents have high and medium levels of emotional exhaustion, depersonalization; 3 ) a quarter of the respondents formed such a phase of emotional burnout as «exhaustion» (emotional deficit, emotional and personal detachment, psychosomatic and psychovegetative disorders). The following levels of development of emotional intelligence were revealed in different groups of medical workers: a) high and medium - among doctors of a surgical profile and doctors of a therapeutic profile; medium - for surgical nurses; low - for therapeutic nurses.

Conclusion. Medical workers with high and medium levels of emotional intelligence have a low level of manifestation of symptoms of emotional burnout (dissatisfaction with oneself; feelings of being caged; anxiety and depression; reduction of professional duties; emotional deficit; personal detachment; psychosomatic and psychovegetative disorders), as well as a low level of development phases of tension, resistance, exhaustion, depersonalization and reduction of personal achievements.

Key words: stress, burnout, burnout symptoms, emotional intelligence, medical workers. 


\section{INTRODUCTION}

The problem of emotional burnout of medical workers is an urgent problem today, since the professional activity of medical workers is associated with constant intense emotionally charged communication, which requires them to have significant emotional resources and skills, such as recognizing a wide range of human emotional expressions, understanding their own emotions and managing them and also the ability to affect the emotional state of patients, etc.

The problem of emotional burnout of medical workers lies not so much in its prevalence, but in the absence of adequate measures for its prevention and, first of all, in the low awareness of the medical workers themselves regarding the characteristics of the emotional sphere and the first signs that indicate the development of emotional burnout.

The analysis of studies of burnout among healthcare workers indicates that a significant percentage of healthcare workers have low resistance to burnout.

Many authors who study the emotional burnout of medical workers point to the essential role of personality factors in preventing the development of its symptoms. Scientists emphasize the importance of developing such qualities as emotional control, emotional stability, resilience, empathy, a positive attitude towards oneself, etc. [1; $2 ; 3 ; 4 ; 5 ; 6 ; 7 ; 14]$ More and more often scientists consider emotional intelligence in the professional activity of medical workers as an integral characteristic of a personality in the context of its adaptive function $[7 ; 8 ; 9 ; 10 ; 12]$. Emotional intelligence is associated with that side of the professional competence of a medical worker, which relies on emotional skills and abilities (understanding one's own emotions and the emotions of other people, the ability to control their emotional states and influence the emotions of other people).

The analysis of studies on the problem of the relationship between the indicators of emotional intelligence and emotional burnout of medical workers showed that emotional intelligence, as an integral construct, can be considered as a personal aspect in the study of the development and manifestation of emotional burnout among medical workers.

\section{PURPOSE OF THE STUDY}

To study the relationship between the characteristics of emotional burnout and indicators of emotional intelligence among medical workers.

\section{MATERIALS AND METHODS}

The study involved 4 groups of respondents (110 medical workers): surgical doctors, therapeutic doctors, surgical nurses, therapeutic nurses). The age of the subjects was from 25 to 65 years.
Evaluation of the emotional burnout and emotional intelligence features was carried out using diagnostic methods of emotional burnout (V. Boyko) [11], the questionnaire of emotional burnout by K. Maslach and S. Jackson (adaptation by N. Vodopyanova) [13] and the method of emotional intelligence (N. Hall) [15].

The study consisted of two stages. The purpose of the first stage was to determine the level and characteristics of the manifestation of emotional burnout of medical workers according to the following symptoms: emotional exhaustion; depersonalization; reduction of personal achievements; «stress» (experiencing traumatic circumstances, dissatisfaction with oneself, feeling caged, anxiety and depression); «resistance» (inadequate selective emotional response, emotional and moral disorientation, expansion of the sphere of saving emotions, reduction of professional duties); «exhaustion» (emotional deficit, emotional detachment, psychosomatic and psychovegetative disorders). The expression level of emotional intelligence of medical workers was also assessed according to the following indicators: emotional awareness, emotion management, self-motivation, empathy, recognizing other people's emotions.

The second stage of the study was aimed at determining the peculiarities of the relationship between individual indicators of emotional burnout with individual indicators of medical workers' emotional intelligence. Mathematical processing of the research results was carried out using the Spearman's correlation coefficient using the SPSS 17 computer program.

\section{RESULTS AND DISCUSSION}

Let's consider the results of an empirical study on the method of emotional burnout by V. Boyko [11]. As can be seen from the results of the study presented in Table 1, the symptom «Experiencing traumatic circumstances» was formed among $27,27 \%$ of respondents, among $18,18 \%$ it is being formed, and among 54,55\% - not formed; the symptom «Dissatisfaction with oneself» - formed among 1,82\% of the respondents, among $16,36 \%$ it is being formed, among $81,82 \%$ - not formed; the symptom «Driven into a cage»-among $2,73 \%$ of the respondents it was formed, among 6,36\% it is being formed, among 90,91\% - not formed; symptom «Anxiety and depression» - formed among 9,09\% of respondents, among $18,18 \%$ it is developing, among 72,73\% - not formed; the symptom «Inadequate emotional selective response» - formed among $30,91 \%$ of respondents, among $32,73 \%$ it is developing, among 36,36\% - not formed; symptom «Emotional and moral disorientation» - formed among $20,00 \%$ of respondents, among $14,55 \%$ it is being formed, among $65,45 \%-$ not developed; the symptom «Expanding the sphere of saving emotions» - developed among 58,18\% of respondents, among 4,55\% it is being formed, among $37,27 \%$ it 
has not developed; the symptom «Reduction of professional duties»-formed among 23,64\% of respondents, among $20,91 \%$ it is developing, among $55,45 \%$ it has not been formed; the symptom «Emotional deficit»-among 8,18\% of respondents it has developed, among $19,09 \%$ it is being formed, among 72,73\% - not formed; the symptom «Emotional detachment» - formed among $13,64 \%$ of respon- dents, among $22,73 \%$ it is being formed, among 63,64\% not formed; the symptom «Personal detachment» - formed among $9,09 \%$ of respondents, among $14,55 \%$ it is being formed, among 76,36\% - not formed; symptom «Psychosomatic and psycho-vegetative disorders»-formed among $10,91 \%$ of respondents, among $17,27 \%$ it is developing, among $71,82 \%$ it has not developed.

\section{Formation levels of individual symptoms of emotional burnout among medical workers according to V. Boyko's method}

\begin{tabular}{|l|c|c|c|c|c|c|}
\hline \multirow{2}{*}{\multicolumn{1}{c|}{ Symptom }} & \multicolumn{3}{c|}{ Symptom development levels } \\
\cline { 2 - 7 } & \multicolumn{2}{|c|}{ Not formed } & \multicolumn{2}{c|}{ Being formed } & \multicolumn{2}{c|}{ Formed } \\
\cline { 2 - 7 } & $\mathbf{N}$ & $\mathbf{\%}$ & $\mathbf{N}$ & $\mathbf{\%}$ & $\mathbf{N}$ & $\mathbf{\%}$ \\
\hline Experiencing traumatic circumstances & 60 & 54,55 & 20 & 18,18 & 30 & 27,27 \\
\hline Dissatisfaction with oneself & 90 & 81,82 & 18 & 16,36 & 2 & 1,82 \\
\hline Driven into a cage & 100 & 90,91 & 7 & 6,36 & 3 & 2,73 \\
\hline Anxiety and depression & 80 & 72,73 & 20 & 18,18 & 10 & 9,09 \\
\hline Inadequate emotional selective response & 40 & 36,36 & 36 & 32,73 & 34 & 30,91 \\
\hline Emotional and moral disorientation & 72 & 65,45 & 16 & 14,55 & 22 & 20,00 \\
\hline Expanding the sphere of saving emotions & 41 & 37,27 & 5 & 4,55 & 64 & 58,18 \\
\hline Reduction of professional duties & 61 & 55,45 & 23 & 20,91 & 26 & 23,64 \\
\hline Emotional deficit & 80 & 72,73 & 21 & 19,09 & 9 & 8,18 \\
\hline Emotional detachment & 70 & 63,64 & 25 & 22,73 & 15 & 13,64 \\
\hline Personal detachment & 84 & 76,36 & 16 & 14,55 & 10 & 9,09 \\
\hline Psychosomatic and psycho-vegetative disorders & 79 & 71,82 & 19 & 17,27 & 12 & 10,91 \\
\hline
\end{tabular}

As can be seen from the results of the study presented in Table 2, such a phase of stress as «stress» (experiencing traumatic circumstances, dissatisfaction with oneself, being caged into a cage, anxiety and depression) is formed among $5,45 \%$ of respondents, among $15,45 \%$ it is being formed and it is not formed among 79,09\% of the respondents.

Such a phase of stress as «resistance» (inadequate selective emotional response, emotional and moral disorientation, expansion of the sphere of saving emotions, reduction of professional duties) is formed among 30,00\% of respondents, is being formed among $36,36 \%$ of respondents and is not formed among 33,64\% respondents.

Such a phase of stress as «exhaustion» (emotional deficit, emotional detachment, personal detachment, psychosomatic and psychovegetative disorders) is formed among $8,18 \%$ of respondents, among $16,36 \%$ it is being formed and it is not formed among $75,45 \%$ of respondents.

Table 2

Stress phases among medical workers according to V. Boyko's method of emotional burnout

\begin{tabular}{|c|c|c|c|c|c|c|}
\hline \multirow{3}{*}{ Phase } & \multicolumn{6}{|c|}{ Phase formation level } \\
\hline & \multicolumn{2}{|c|}{ Has not been formed } & \multicolumn{2}{|c|}{ Being formed } & \multicolumn{2}{|c|}{ Formed } \\
\hline & $\mathbf{N}$ & $\%$ & $\mathbf{N}$ & $\%$ & $\mathbf{N}$ & $\%$ \\
\hline Stress & 87 & 79,09 & 17 & 15,45 & 6 & 5,45 \\
\hline Resistance & 37 & 33,64 & 40 & 36,36 & 33 & 30,00 \\
\hline Exhaustion & 83 & 75,45 & 18 & 16,36 & 9 & 8,18 \\
\hline
\end{tabular}

Next, we will consider the results of an empirical study based on Maslach's «Burnout Syndrome» method. As can be seen from the research results presented in table 3:

- 13,91\% of respondents have a high expression level of emotional exhaustion (experiencing a reduced emotional tone, increased mental exhaustion and affective lability, loss of interest and positive feelings towards others, a feeling of «oversaturation» with work, dissatisfaction with life in general), 36,52\% - medium and 49,57\% - low;

- $15,65 \%$ of respondents have a high expression level of depersonalization (emotional detachment and indif- ference, formal performance of professional duties without personal involvement and empathy, and in some cases - in negativity and cynical attitude), 29,57\% - medium and $54,78 \%$ - low;

- $32,17 \%$ of respondents have a high expression level of a reduction in personal achievements (negative assessment of their competence and productivity, a decrease in professional motivation, an increase in negativism regarding official duties, a tendency to relinquish responsibility, to isolate from others, detachment, avoidance of work), 35,65\%medium and $32,17 \%$ - low. 
The level of manifestation of phases according to Maslach's «Burnout Syndrome» method

\begin{tabular}{|c|c|c|c|c|c|c|}
\hline \multirow{3}{*}{ Phase } & \multicolumn{6}{|c|}{ Levels } \\
\hline & \multicolumn{2}{|c|}{ Law } & \multicolumn{2}{|c|}{ Medium } & \multicolumn{2}{|c|}{ High } \\
\hline & $\mathbf{N}$ & $\%$ & $\mathbf{N}$ & $\%$ & $\mathbf{N}$ & $\%$ \\
\hline Emotional exhaustion & 57 & 49,57 & 42 & 36,52 & 16 & 13,91 \\
\hline Depersonalization & 63 & 54,78 & 34 & 29,57 & 18 & 15,65 \\
\hline Reduction in personal achievements & 37 & 32,17 & 41 & 35,65 & 37 & 32,17 \\
\hline
\end{tabular}

Let's consider the results of an empirical study using the «Emotional intelligence» method by N. Hall [15]. As can be seen from the results presented in

Table 4 , among $13,27 \%$ of medical workers there is a high level of emotional intelligence, $38,94 \%$ - average, $47,79 \%$ - low.

Table 4

General emotional intelligence among healthcare professionals

\begin{tabular}{|c|c|c|c|c|c|c|}
\hline \multirow{2}{*}{ Index of } & \multicolumn{6}{|c|}{ Level of emotional intelligence } \\
\cline { 2 - 7 } & \multicolumn{2}{|c|}{ Law } & \multicolumn{2}{|c|}{ Average } & \multicolumn{3}{c|}{ High } \\
\cline { 2 - 7 } & $\mathbf{N}$ & $\mathbf{N}$ & $\mathbf{N}$ & $\mathbf{N}$ & $\mathbf{N}$ & \% \\
\hline Emotional intelligence & 54 & 47,79 & 44 & 38,94 & 15 & 13,27 \\
\hline
\end{tabular}

As can be seen from the results of the study presented in Table 5, among 13,89\% of therapeutic profile physicians there is a high level of emotional intelligence, $44,44 \%$ have an average level, 41,67\% have a low level; $23,81 \%$ of surgical profile doctors have a high level of emotional in-

General level of emotional intelligence among health care workers of different groups

\begin{tabular}{|l|c|c|c|c|c|c|}
\hline \multirow{2}{*}{\multicolumn{2}{c|}{ Groups of subjects }} & \multicolumn{9}{c|}{ Level of emotional intelligence } \\
\cline { 2 - 8 } & \multicolumn{2}{|c|}{ Law } & \multicolumn{3}{c|}{ Average } & \multicolumn{3}{c|}{ High } \\
\cline { 2 - 8 } & $\mathrm{N}$ & $\%$ & $\mathrm{~N}$ & $\%$ & $\mathrm{~N}$ & $\%$ \\
\hline Therapeutic profile physicians & 15 & 41,67 & 16 & 44,44 & 5 & 13,89 \\
\hline Surgical profile physicians & 9 & 42,86 & 7 & 33,33 & 5 & 23,81 \\
\hline Therapeutic nurses & 17 & 60,71 & 6 & 21,43 & 5 & 17,86 \\
\hline Surgical nurses & 13 & 46,43 & 15 & 53,57 & 0 & 0 \\
\hline
\end{tabular}

As can be seen from the results of the study presented in Table 6: among therapeutic profile physicians only $30,56 \%$ of respondents have high level of emotional awareness, 36,11\% - average, 33,33\% - low; among physicians of the surgical profile, $38,10 \%$ - high level of emotional awareness, 33,33\% - average, 28,57\% - low; among nurses of the therapeutic profile, $28,57 \%$ of respondents - high, $28,57 \%$ - average, $42,86 \%$ - low; among nurses of the surgical profile, $7,14 \%$ of respondents have shown high level of emotional awareness, 53,57\% - average, 39,29\% - low.

As for the indicator «understanding one's own emotions»: among physicians of the therapeutic profile, $8,33 \%$ of respondents have high level, $30,56 \%$ - average, $61,11 \%$ - low; among doctors of a surgical profile, $4,76 \%$ of respondents have high expression level, $42,86 \%$ - average, 52,38\% - low; among nurses of a therapeutic profile, $10,71 \%$ of respondents have a high level of manifestation, average - 10,71\%, 78,57\% - low; among nurses of a surgical profile, $10,71 \%$ of respondents - high level, among $21,43 \%$ it's average, $67,86 \%-$ low.

According to the indicator «self-motivation»: among therapeutic profile physicians, 19,44\% have high level, telligence, 33,33\% - average, 42,86\% - low; among nurses of a therapeutic profile, 17,86\% have a high level of emotional intelligence, 21,43\% - average, 60,71\% - low; among nurses of a surgical profile, $53,57 \%$ have an average level of emotional intelligence, $46,43 \%$ have a low level.

Table 5
$33,33 \%$ - average, 47,22\% - low; among surgical profile physicians, 38,10\% - high, 19,05\% - average, $42,86 \%$ low; as for the therapeutic nurses, a high level of manifestation is observed among $28,57 \%$ of respondents, $21,43 \%-$ average, $50,00 \%$ - low; $14,29 \%$ of surgical nurses have high level, $50,00 \%$ - average, $35,71 \%$ - low.

According to the «empathy» indicator: among therapeutic profile physicians, 25,00\% - high level, 41,67\%average, $33,33 \%$ - low; among surgical profile physicians, a high level of manifestation is observed in $28,57 \%$ of respondents, medium - in 33,33\%, low - in 38,10\%; among nurses of the therapeutic profile, $32,14 \%$ - high level, $25,00 \%-$ average, $42,86 \%$ - low; among surgical nurses, $17,86 \%$ high, 57,14\% - average, 25,00\% - low.

As for the indicator «managing others' emotions»: $25,00 \%$ of therapeutic profile physicians have high level of manifestation, 41,67\% - average, 33,33\% - low; among surgical profile physicians, 19,05\% - high, 33,33\% - average, $47,62 \%$ - low; $21,43 \%$ of therapeutic profile nurses have high level, 39,29\% - average level of ability to control others'emotions, $39,29 \%$ - low; among nurses of the surgical profile, $10,71 \%-$ high level of manifestation, 39,29\% - average, 50,00\% - low. 
The manifestation levels of individual indicators of emotional intelligence among different groups of medical workers

\begin{tabular}{|c|c|c|c|c|c|c|c|c|}
\hline \multirow{3}{*}{$\begin{array}{c}\text { The manifestation level } \\
\text { of indicators of emotional } \\
\text { intelligence }\end{array}$} & \multicolumn{8}{|c|}{ Test subjects groups } \\
\hline & \multicolumn{2}{|c|}{ Therapeutic profile physicians } & \multicolumn{2}{|c|}{ Surgical profile physicians } & \multicolumn{2}{|c|}{ Therapeutic nurses } & \multicolumn{2}{|c|}{ Surgical nurses } \\
\hline & $\mathrm{N}$ & $\%$ & $\mathrm{~N}$ & $\%$ & $\mathrm{~N}$ & $\%$ & $\mathrm{~N}$ & $\%$ \\
\hline $\begin{array}{l}\text { Emotional awareness } \\
\text { high } \\
\text { average } \\
\text { low } \\
\end{array}$ & $\begin{array}{l}11 \\
13 \\
12\end{array}$ & $\begin{array}{l}30,56 \\
36,11 \\
33,33\end{array}$ & $\begin{array}{l}8 \\
7 \\
6 \\
\end{array}$ & $\begin{array}{l}38,10 \\
33,33 \\
28,57\end{array}$ & $\begin{array}{c}8 \\
8 \\
12 \\
\end{array}$ & $\begin{array}{l}28,57 \\
28,57 \\
42,86\end{array}$ & $\begin{array}{c}2 \\
15 \\
11\end{array}$ & $\begin{array}{c}7,14 \\
53,57 \\
39,29\end{array}$ \\
\hline $\begin{array}{l}\text { Understanding one's own } \\
\text { emotions } \\
\text { high } \\
\text { average } \\
\text { low }\end{array}$ & $\begin{array}{c}3 \\
11 \\
22\end{array}$ & $\begin{array}{c}8,33 \\
30,56 \\
61,11\end{array}$ & $\begin{array}{c}1 \\
9 \\
11\end{array}$ & $\begin{array}{c}4,76 \\
42,86 \\
52,38\end{array}$ & $\begin{array}{c}3 \\
3 \\
22\end{array}$ & $\begin{array}{l}10,71 \\
10,71 \\
78,57\end{array}$ & $\begin{array}{c}3 \\
6 \\
19\end{array}$ & $\begin{array}{l}10,71 \\
21,43 \\
67,86\end{array}$ \\
\hline $\begin{array}{l}\text { Self-motivation } \\
\text { high } \\
\text { average } \\
\text { low } \\
\end{array}$ & $\begin{array}{c}7 \\
12 \\
17\end{array}$ & $\begin{array}{l}19,44 \\
33,33 \\
47,22 \\
\end{array}$ & $\begin{array}{l}8 \\
4 \\
9 \\
\end{array}$ & $\begin{array}{l}38,10 \\
19,05 \\
42,86 \\
\end{array}$ & $\begin{array}{c}8 \\
6 \\
14 \\
\end{array}$ & $\begin{array}{l}28,57 \\
21,43 \\
50,00\end{array}$ & $\begin{array}{c}4 \\
14 \\
10\end{array}$ & $\begin{array}{l}14,29 \\
50,00 \\
35,71 \\
\end{array}$ \\
\hline $\begin{array}{l}\text { Empathy } \\
\text { high } \\
\text { average } \\
\text { low } \\
\end{array}$ & $\begin{array}{c}9 \\
15 \\
12 \\
\end{array}$ & $\begin{array}{l}25,00 \\
41,67 \\
33.33 \\
\end{array}$ & $\begin{array}{l}6 \\
7 \\
8 \\
\end{array}$ & $\begin{array}{l}28,57 \\
33,33 \\
38,10 \\
\end{array}$ & $\begin{array}{c}9 \\
7 \\
12 \\
\end{array}$ & $\begin{array}{l}32,14 \\
25,00 \\
42,86 \\
\end{array}$ & $\begin{array}{c}5 \\
16 \\
7 \\
\end{array}$ & $\begin{array}{l}17,86 \\
57,14 \\
25,00 \\
\end{array}$ \\
\hline $\begin{array}{l}\text { Managing others' emotions } \\
\text { high } \\
\text { average } \\
\text { low }\end{array}$ & $\begin{array}{c}9 \\
15 \\
12\end{array}$ & $\begin{array}{l}25,00 \\
41,67 \\
33,33\end{array}$ & $\begin{array}{c}4 \\
7 \\
10\end{array}$ & $\begin{array}{l}19,05 \\
33,33 \\
47,62\end{array}$ & $\begin{array}{c}6 \\
11 \\
11\end{array}$ & $\begin{array}{l}21,43 \\
39,29 \\
39,29\end{array}$ & $\begin{array}{c}3 \\
11 \\
14\end{array}$ & $\begin{array}{l}10,71 \\
39,29 \\
50,00\end{array}$ \\
\hline
\end{tabular}

As a result of empirical research the following features of emotional burnout at medical workers were established: half of the test subjects have high and medium levels of emotional exhaustion (experiencing reduced emotional tone, increased mental exhaustion and affective lability, loss of interest and positive feelings towards others, feelings of «oversaturation» with work, dissatisfaction with life in general), depersonalization (emotional indifference, formal performance of professional duties without personal involvement and empathy, or in some cases - with negativism and cynicism) and among the vast majority there is a high and medium level of personal achievements reduction (negative assessment of their competence and productivity, reduced professional motivation, growing negativism in relation to official duties, the tendency to absolve oneself of responsibility, to isolate oneself from others, detachment, avoidance of work).

Among the vast majority of health professionals: a) the phase of stress called «stress» (experiencing traumatic circumstances, dissatisfaction with oneself, confinement, anxiety and depression) wasn't formed; b) the phase of stress called «resistance» (inadequate selective emotional response, emotional and moral disorientation, expanding the scope of saving emotions, reduction of professional responsibilities) is being formed or is already formed; c) there is also a high and medium level of emotional intelligence and emotional awareness, self-motivation, empathy and the ability to manage others' emotions; d) a third of health workers have high and medium levels of ability to manage their own emotions; e) a quarter of health workers have a phase of stress called «exhaustion» (emotional deficit, emotional alienation, personal alienation, psychosomatic and psychovegetative disorders).

The measure of emotional intelligence development is specific to different groups of health professionals and has the following levels: a) high and medium - among general and surgical doctors; middle - among nurses of the surgical department; low level - among general nurses and representatives of other professions of the medical institution.

We used Spearman's correlation analysis to assess the relationship between burnout and emotional intelligence among healthcare professionals (therapeutic doctors, surgical doctors, therapeutic nurses, and surgical nurses).

As a result of the analysis of the relationship between the indicators of emotional burnout and indicators of emotional intelligence among medical workers, the following features were revealed (table 7).

The higher the general level of emotional intelligence, the lower the expression level of emotional burnout symptoms such as: dissatisfaction with oneself $(\mathrm{r}=-0,217$ at $\mathrm{p} \leq 0,025)$, feeling driven into a cage $(\mathrm{r}=-0,230$ at $\mathrm{p} \leq 0,017)$, anxiety and depression $(\mathrm{r}=-0,226$ at $\mathrm{p} \leq 0,019)$, reduction of professional duties $(r=-0,224$ at $p \leq 0,02)$, emotional deficit $(r=-0,291$ at $p \leq 0,002)$, personal detachment $(\mathrm{r}=-0,286$ at $\mathrm{p} \leq 0,003)$, psychosomatic and psychovegetative disorders $(\mathrm{r}=-0,258$ at $\mathrm{p} \leq 0,007)$, as well as lower levels of stress $(r=-0,230$ at $\mathrm{p} \leq 0,017)$, resistance $(r=-0,229$ at $\mathrm{p} \leq 0,018)$, exhaustion $(\mathrm{r}=-0,311$ at $\mathrm{p} \leq 0,001)$, depersonalization $(\mathrm{r}=-0,222$ at $\mathrm{p} \leq 0,018)$, and less often there are signs of reduction in personal achievements $(\mathrm{r}=0,458$ at $\mathrm{p} \leq 0,000)$. 
The relationship between burnout and emotional intelligence of healthcare workers (Spearman's r-correlation coefficient)

\begin{tabular}{|c|c|c|c|c|c|c|}
\hline \multirow[b]{2}{*}{ Burnout metrics } & \multicolumn{6}{|c|}{ Emotional intelligence scores } \\
\hline & $\begin{array}{l}\text { Emotional } \\
\text { awareness }\end{array}$ & $\begin{array}{l}\text { Understanding } \\
\text { one's own } \\
\text { emotions }\end{array}$ & $\begin{array}{c}\text { Self- } \\
\text { motivation }\end{array}$ & Empathy & \begin{tabular}{|c|} 
Recognizing \\
other \\
people's \\
emotions \\
\end{tabular} & $\begin{array}{c}\text { Overall } \\
\text { Emotional } \\
\text { Intelligence }\end{array}$ \\
\hline \multirow{2}{*}{$\begin{array}{l}\text { Experiencing traumatic } \\
\text { circumstances }\end{array}$} & $-0,046$ &,$- 230^{*}$ & $-0,104$ & $-0,092$ & $-0,05$ & $-0,128$ \\
\hline & 0,636 & 0,017 & 0,284 & 0,345 & 0,612 & 0,188 \\
\hline \multirow{2}{*}{ Dissatisfaction with oneself } &,$- 210^{*}$ & $-0,172$ & $-0,177$ & $-0,121$ &,$- 222^{*}$ &,$- 217^{*}$ \\
\hline & 0,03 & 0,076 & 0,068 & 0,213 & 0,022 & 0,025 \\
\hline \multirow{2}{*}{ Trapped in a cage } &,$- 207^{*}$ & $-0,189$ & $-0,096$ & $-0,18$ &,$- 192^{*}$ &,$- 230^{*}$ \\
\hline & 0,032 & 0,051 & 0,326 & 0,063 & 0,047 & 0,017 \\
\hline \multirow{2}{*}{ Anxiety and depression } & $-0,112$ &,$- 215^{*}$ & $-0,162$ & $-0,104$ & $-0,163$ &,$- 226^{*}$ \\
\hline & 0,252 & 0,026 & 0,095 & 0,285 & 0,094 & 0,019 \\
\hline \multirow{2}{*}{$\begin{array}{l}\text { Inappropriate emotional } \\
\text { selective response }\end{array}$} & $-0,078$ & $-0,182$ & $-0,145$ & $-0,048$ & $-0,026$ & $-0,129$ \\
\hline & 0,422 & 0,061 & 0,136 & 0,626 & 0,787 & 0,185 \\
\hline \multirow{2}{*}{$\begin{array}{c}\text { Emotional and moral } \\
\text { disorientation }\end{array}$} & $-0,093$ & $-0,048$ & $-0,128$ & $-0,106$ & $-0,098$ & $-0,138$ \\
\hline & 0,338 & 0,621 & 0,189 & 0,278 & 0,315 & 0,157 \\
\hline \multirow{2}{*}{$\begin{array}{l}\text { Expanding the sphere of } \\
\text { saving emotions }\end{array}$} & $-0,136$ & $-0,178$ & $-0,072$ & $-0,123$ & $-0,124$ & $-0,134$ \\
\hline & 0,161 & 0,067 & 0,461 & 0,208 & 0,204 & 0,17 \\
\hline \multirow{2}{*}{$\begin{array}{l}\text { Reduction of professional } \\
\text { duties }\end{array}$} & $-0,126$ &,$- 194^{*}$ &,$- 200^{*}$ & $-0,168$ & $-0,177$ &,$- 224 *$ \\
\hline & 0,197 & 0,045 & 0,039 & 0,083 & 0,068 & 0,02 \\
\hline \multirow{2}{*}{ Emotional deficit } &,$- 217^{*}$ &,$- 257^{* *}$ &,$- 264 * *$ &,$- 276^{* *}$ &,$- 271^{* *}$ &,$- 291 * *$ \\
\hline & 0,025 & 0,008 & 0,006 & 0,004 & 0,005 & 0,002 \\
\hline \multirow{2}{*}{ Emotional detachment } & $-0,057$ & $-0,115$ & $-0,179$ & $-0,184$ & $-0,175$ & $-0,156$ \\
\hline & 0,557 & 0,239 & 0,065 & 0,058 & 0,071 & 0,109 \\
\hline \multirow{2}{*}{ Personal detachment } &,$- 248^{* *}$ &,$- 357 * *$ &,$- 255^{* *}$ &,$- 215^{*}$ & $-0,12$ &,$- 286^{* *}$ \\
\hline & 0,01 & 0 & 0,008 & 0,026 & 0,218 & 0,003 \\
\hline \multirow{2}{*}{$\begin{array}{c}\text { Psychosomatic and } \\
\text { psychovegetative disorders }\end{array}$} & $-0,104$ &,$- 352 * *$ &,$- 228^{*}$ & $-0,171$ &,$- 192^{*}$ &,$- 258^{* *}$ \\
\hline & 0,288 & 0 & 0,018 & 0,079 & 0,047 & 0,007 \\
\hline \multirow{2}{*}{ Stress } & $-0,142$ &,$- 260 * *$ & $-0,143$ & $-0,163$ & $-0,17$ &,$- 230^{*}$ \\
\hline & 0,146 & 0,007 & 0,143 & 0,093 & 0,08 & 0,017 \\
\hline \multirow{2}{*}{ Resistance } & $-0,166$ &,$- 247^{*}$ & $-0,179$ & $-0,181$ & $-0,174$ &,$- 229 *$ \\
\hline & 0,088 & 0,01 & 0,065 & 0,063 & 0,072 & 0,018 \\
\hline \multirow{2}{*}{ Exhaustion } &,$- 191^{*}$ &,$- 343^{* *}$ &,$- 299 * *$ &,$- 251^{* *}$ &,$- 240^{*}$ &,$- 311^{* *}$ \\
\hline & 0,049 & 0 & 0,002 & 0,009 & 0,013 & 0,001 \\
\hline \multirow{2}{*}{ Emotional exhaustion } & $-0,026$ &,$- 230^{*}$ & $-0,037$ & $-0,027$ & $-0,029$ & $-0,103$ \\
\hline & 0,784 & 0,014 & 0,697 & 0,774 & 0,763 & 0,278 \\
\hline \multirow{2}{*}{ Depersonalization } & $-0,175$ &,$- 262 * *$ & $-0,168$ & $-0,145$ & $-0,138$ &,$- 222 *$ \\
\hline & 0,064 & 0,005 & 0,076 & 0,125 & 0,144 & 0,018 \\
\hline \multirow{2}{*}{$\begin{array}{l}\text { Reduction of personal } \\
\text { achievements }\end{array}$} &, $369 * *$ &, $314^{* *}$ &, $372^{* *}$ &, $421 * *$ &, $464 * *$ &, $458 * *$ \\
\hline & 0 & 0,001 & 0 & 0 & 0 & 0 \\
\hline
\end{tabular}

$*-\mathrm{p} \leq 0,05, * *-\mathrm{p} \leq 0,01$ 
The higher the emotional awareness, the lower expression level of emotional burnout symptoms such as: dissatisfaction with oneself $(r=-0,210$ at $p \leq 0,03)$; feeling driven into a cage $(\mathrm{r}=-0,207$ at $\mathrm{p} \leq 0,032)$; emotional deficit $(\mathrm{r}=-0,217$ at $\mathrm{p} \leq 0,025)$; personal detachment $(\mathrm{r}=$ $0,248$ at $\mathrm{p} \leq 0,01)$; and also the lower level of eshaustion $(\mathrm{r}=-0,191$ at $\mathrm{p} \leq 0,049)$ and display of personal achievements reduction $(\mathrm{r}=0,369$ at $\mathrm{p} \leq 0,000)$.

The higher the level of ability to manage one's own emotions, the lower the expression level of emotional burnout symptoms such as: experiencing traumatic circumstances $(\mathrm{r}=-0,230$ at $\mathrm{p} \leq 0,017)$, anxiety and depression $(\mathrm{r}=-0,215$ at $\mathrm{p} \leq 0,026)$, reduction of professional duties $(\mathrm{r}=-0,194$ at $\mathrm{p} \leq 0,045)$, emotional deficit $(\mathrm{r}=-0,257$ at $\mathrm{p} \leq 0,008)$, personal detachment $(\mathrm{r}=-0,357$ at $\mathrm{p} \leq 0,000)$, psychosomatic and psychovegetative disorders $(\mathrm{r}=-0,352$ at $\mathrm{p} \leq 0,000)$, emotional exhaustion $(\mathrm{r}=-0,230$ at $\mathrm{p} \leq 0,014)$, depersonalization $(r=-0,262$ at $p \leq 0,005)$, reduction of personal achievements $(r=0,314$ at $p \leq 0,001)$, as well as a lower level of stress $(r=-0,260$ at $p \leq 0,007)$, resistance $(r=-0,247$ at $\mathrm{p} \leq 0,01)$ and exhaustion $(\mathrm{r}=-0,343$ at $\mathrm{p} \leq 0,000)$.

Developed self-motivation reduces the possibility of reduction in professional duties $(r=-0,200$ at $\mathrm{p} \leq 0,039)$; emotional deficit $(\mathrm{r}=-0,264$ at $\mathrm{p} \leq 0,006)$; personal detachment $(\mathrm{r}=-0,255$ at $\mathrm{p} \leq 0,008)$; psychosomatic and psychovegetative disorders $(\mathrm{r}=-0,228$ at $\mathrm{p} \leq 0,018)$; exhaustion $(r=0,299$ at $p \leq 0,002)$ and signs of reduction in personal achievements $(r=0,372$ at $p \leq 0,000)$.

The higher the level of empathy, the lower expressions of symptoms such as: emotional deficit $(r=-0,276$ at $\mathrm{p} \leq 0,004)$; personal detachment $(\mathrm{r}=-0,215$ at $\mathrm{p} \leq 0,026)$; as well as the appearance of the emotional burnout phase like «exhaustion» $(\mathrm{r}=-0,251$ at $\mathrm{p} \leq 0,009)$ and signs of personal achievement reduction $(r=0,421$ at $p \leq 0,000)$.

The higher development level of the ability to recognize other people's emotions, the lower manifestations such as: dissatisfaction with oneself $(r=-0,222$ at $\mathrm{p} \leq 0,022)$; being driven into a cage $(\mathrm{r}=-0,192$ at $\mathrm{p} \leq 0,047)$; emotional deficit ( $\mathrm{r}=-0,271$ at $\mathrm{p} \leq 0,005)$; psychosomatic and psychovegetative disorders $(r=-0,192$ at $\mathrm{p} \leq 0,047)$, as well as the level of exhaustion $(r=0,240$ at $p \leq 0,013)$ and reduction of personal achievements $(r=0,464$ at $\mathrm{p} \leq 0,000)$.

\section{CONCLUSION}

The use of correlation analysis made it possible to reveal the following interrelationships between the indicators of burnout and emotional intelligence among medical workers: medical workers with high and medium levels of emotional intelligence have a low expression level of emotional burnout symptoms such as dissatisfaction with themselves, feeling caged, anxiety and depression, reduction duties, emotional deficit, personal detachment, psychosomatic and psychovegetative disorders, as well as a low level of tension, resistance, exhaustion, depersonalization and reduction of personal achievements.

Early diagnosis of the emotional burnout expression enables a person to mobilize internal resources, as well as apply coping techniques.

\section{ЛИТЕРАТУРА}

1. Акиндинова И. А. Методы психологической помощи работе с последствиями синдрома эмоционального выгорания специалистов помогающих профессий. Психологический журнал. 2001. Т. 17. № 4. С. 56-72.

2. Бойко В. В. Синдром эмоционального выгорания в профессиональном общении. СПб., 1999. 105 с.

3. Ващенко І.В., Леженіна Л. М. Поняття «емоційного вигорання» в психології. Психологічні перспективи: Збірник наук. праць Волинського нац. ун-ту ім. Лесі Українки. Луцьк: Вид-во ВНУ, 2008. № 11. С. 15-25.

4. Драга Т. М., Мялюк О. П., Криницька І. Я. Ососбливості синдрому емоційного вигорання у медичних працівників. Медсестринство. 2017. № 3. C. 48-51.

5. Эмоциональное выгорание у врачей и медицинские ошибки. Есть ли связь? / Кобякова О. С., Деев И. А., Куликов Е. С., Пименов И. Д., Хомяков К. В.
Социальные аспекты здоровья населения. 2016. 1. C. 5-18.

6. Кузнецова О.А., Лепехин Н. Н. Психологические особенности синдрома выгорания у врачей анестезиологов-ревматологов. Современные проблемы исследования синдрома выгорания у специалистов коммуникативных профессий / под ред. В. В. Лукьянова и др. Курск: Курск. гос. ун-т, 2008. C. 220-227.

7. Любіна Л.А., Тимофієва М. П., Осипенко В. А. Емоційна компетентність як показник психологічного здоров'я особистості майбутніх лікарів. Psychological journal. 2018. № 5 (15). С. 81-97.

8. Люсин Д.В., Ушаков Д. В. Социальный и эмоциональный интеллект: От процессов к измерениям: Введение / под ред. Д. В. Люсина, Д. В. Ушакова. М.: Институт психологии РАН, 2009. С. 5-9.

9. Максименко С.Д.., Хаустов Е. А. Теоретикометодологический генезис выгорания медицин- 
ских работников. Проблеми сучасної психології. 2013. Випуск 19. С. 7-23

10. Манянина Т. В. Эмоциональный интеллект в структуре психологической культуры личности: автореф. дис. канд. психолог. наук. Барнаул, 2010. 22 с.

11. Методика диагностики эмоционального выгорания / В. В. Бойко. URL: https://psytests.org/boyko/ burnout.html

12.Носенко Е.Л., Коврига Н. В. Емоційний інтелект: концептуалізація феномену, основні функціі. Киев: Вища школа, 2003. 126 с.

13.Опросник «Профессиональное (эмоциональное) выгорание». Методика / К. Маслач и С. Джексон. URL: https://psycabi.net/ testy/391-oprosnik-professionalnoe-emotsionalnoevygoranie-pv-metodika-k-maslach-i-s-dzheksonadaptatsiya-n-vodopyanova-e-starchenkova-testydlya-diagnostiki-sindroma-pv

14. Пилипенко Н. Г. Особливості емоційного вигорання у медичних працівників. Інтеграційний розвиток особистості та суспільства: психологічний і соціологічний виміри: матеріали II міжнарод. наук.-практ. конф. / за ред.д.ю.н., проф. Аракелян М. Р.; Національний університет «Одеська юридична академія». Одеса: Гельветика, 2020. $316 \mathrm{c}$.

15.Тест эмоционального интеллекта Холла. URL: https://psylab.info/

\section{REFERENCES}

1. Akindinova, I.A. (2001). Metody' psikhologicheskoj pomoshhi rabote s posledstviyami sindroma e'moczional'nogo vy'goraniya speczialistov pomogayushhikh professij [Methods of psychological assistance to work with the consequences of burnout syndrome for specialists in helping profession]. Psychological journal, 17, 4, 56-72.

2. Boyko, V.V. (1999). Sindrom e'moczional'nogo vy'goraniya $\mathrm{v}$ professional'nom obshhenii [Burnout syndrome in professional communication]. SPb., 105.

3. Vashhenko, I'.V., Lezheni'na, L.M. (2008). Ponyattya «emoczi'jnogo vigorannya» v psikhologi'yi [Understanding the «emotional vigorannya» in psychology]. Psychological perspectives: Collection of Science Practitioners of the Volynsky National University to Lesia Ukrayinka. Lucz'k: Vid-vo VNU, 1, 15-25.

4. Draga, T. M., Myalyuk, O. P., Krinicz'ka, I'. Ya. (2017). Ososblivosti' sindromu emoczi'jnogo vigorannya u medichnikh praczi'vniki'v [Specificity to the syndrome of emotional vigoranny in medical practitioners]. Nursing, 3, 48-51.

5. Kobyakova, O.S., Deev, I.A., Kulikov, E.S., Pimenov, I.D., Khomyakov, K.V. (2016). E'moczional'noe vy'goranie u vrachej i mediczinskie oshibki. Est' li svyaz'? [Burnout in doctors and medical errors. Is there a connection?]. Social aspects of population health, 1, 5-18.

6. Kuzneczova, O.A., Lepekhin, N.N. (2008). Psikhologicheskie osobennosti sindroma vy'goraniya u vrachej anesteziologov-revmatologov [Psychological features of burnout syndrome in anesthesiologists-rheumatologists]. Modern problems in the study of burnout syndrome in specialists of communication professions / Kursk: Kursk. gos. un-t, 220-227.

7. Lyubi'na, L.A., Timofi'yeva, M.P., Osipenko, V.A. (2018). Emoczi'jna kompetentni'st' yak pokaznik psikhologi'chnogo zdorov'ya osobistosti' majbutni'kh li'kari'v [Emotional competence as an indicator of psychological health]. Psychological journal, 5 (15), 81-97.

8. Lyusin, D.V., Ushakov, D.V. (2009). Soczial'ny'j i e'moczional'ny'j intellekt: Ot proczessov k izmereni- yam [Social and Emotional Intelligence: From Processes to Measurements]. Izd-vo Institut psikhologii RAN, 5-9.

9. Maksimenko, S.D., Khaustova, E.A. (2013). Teoretikometodologicheskij genezis vy'goraniya u mediczinskikh rabotnikov [Theoretical and methodological genesis of burnout in healthcare workers]. Problems of current psychology, 19, 7-23

10. Manyanina, T.V. (2010). E'moczional'ny'j intellekt v strukture psikhologicheskoj kul'tury' lichnosti: avtoref. dis. kand. psikholog. nauk. [Emotional intelligence in the structure of the psychological culture of a personality]. Barnaul, 22.

11. Metodika diagnostiki e'moczional'nogo vy'goraniya V. V. Bojko [Burnout diagnostic technique]. Retrieved from: https://psytests.org/boyko/burnout.html

12. Nosenko, E.L., Kovriga, N.V. (2003). Emoczijnij intelekt: konczeptualizacziya fenomenu, osnovni funkczii [Emotional intellect: conceptualization of the phenomenon, basic functions]. Kiev: Vishha shkola, 126.

13. Oprosnik «Professional'noe (e'moczional'noe) vy'goranie». Metodika K. Maslach i S. Dzhekson. [Questionnaire «Professional (emotional) burnout». Methodology K. Maslach and S. Jackson]. Retrieved from: https:// psycabi.net/testy/391-oprosnik-professionalnoeemotsionalnoe-vygoranie-pv-metodika-k-maslach-i-sdzhekson-adaptatsiya-n-vodopyanova-e-starchenkovatesty-dlya-diagnostiki-sindroma-pv

14.Pilipenko, N.G. (2020). Osoblivosti' emoczi'jnogo vigorannya u medichnikh praczi'vniki'v [Peculiarities of the emotsionny vygorannya at medical workers] Integral development of the specialty and support: psychological and sociological vimir: materials of the 2nd international scientific and practical conference: Naczi'onal'nij uni'versitet «Odes'ka yuridichna akademi'ya». Odesa: Vidavnichij di'm «Gel'vetika», 316.

15. Hall's emotional intelligence test [Hall's emotional intelligence test]. Retrieved from: https://psylab.info/ 


\section{Резюме}

\section{АНАЛІЗ ВЗАЄМОЗВ'ЯЗКІВ ОСОБЛИВОСТЕЙ ЕМОЦІЙНОГО ВИГОРЯННЯ ТА ПОКАЗНИКІВ ЕМОЦІЙНОГО ІНТЕЛЕКТУ У МЕДИЧНИХ ПРАЦІВНИКІВ \\ Н. Г. Пилипенко, О. О. Сидоренко}

Державна наукова установа «Науково-практичний центр профілактичної та клінічної медицини» Державного управління справами, м.Київ, Україна

Мета роботи - представлені результати статистичного аналізу взаємозв'язків особливостей емоційного вигоряння і показників емоційного інтелекту у медичних працівників.

Матеріали і методи - в дослідженні взяло участь 4 групи респондентів (110 медичних працівників): лікарі хірургічного профілю, Аікарі терапевтичного профілю, медсестри хірургічного профілю, медсестри терапевтичного профілю. Оцінка особливостей емоційного вигоряння і емоційного інтелекту проводилася за допомогою діагностичних методик емоційного вигоряння (В.В.Бойко), опитувальника емоційного вигоряння К. Маслач і С.Ажексон (адаптація Н. Водопьянової) і методики емоційного інтелекту (Н. Холл). Аослідження складалося з двох етапів. Метою першого етапу було визначення рівня і особливостей прояву емоційного вигоряння медичних працівників за такими симптомами: (емоційне виснаження; деперсоналізація; редукція особистісних досягнень; «напруга» (переживання психотравмуючих обставин, незадоволеність собою, загнаність в клітку, тривога і депресія); «резистенція» (неадекватне виборче емоційне реагування, емоційно-моральна дезорієнтація, розширення сфери економії емоцій, редукція професійних обов'язків); «виснаження» (емоційний дефіцит, емоційна відстороненість, психосоматичні і психовегетативні порушення). Також була проведена оцінка рівня прояву емоційного інтелекту медичних працівників за такими показниками: емоційна обізнаність, управління емоціями, самомотивація, емпатія, розпізнавання емоцій інших людей. Аругий етап досліАження був спрямований на визначення особливостей взаємозв'язку окремих показників емоційного вигоряння з окремими показниками емоційного інтелекту медичних працівників. Математичну обробку результатів досліАження проводили з використанням коефіцієнта кореляції Спірмена засобами комп'ютерної програми SPSS 17. Результати дослідження і їх обговорення. Результати нашого дослідження показали, що: 1) у переважної більшості випробовуваних спостерігається високий і середній рівні редукції особистісних досягнень, а також сформована або знаходиться в стадії формування така фаза емоційного вигорання, як «резистенція» (неадекватне виборче емоційне реагування, емоційно-моральна дезорієнтація, розширення сфери економії емоцій, редукція професійних обов'язків); 2) у половини випробовуваних спостерігається високий і середній рівні емоційного виснаження, деперсоналізації; 3) у чверті респондентів сформована така фаза емоційного вигорання, як «виснаження» (емоційний дефіцит, емоційна і особистісна відстороненість, психосоматичні і психовегетативні порушення). Виявлено такі рівні розвитку емоційного інтелекту у різних груп медичних працівників: а) високий і середній - у лікарів хірургічного профілю та лікарів терапевтичного профілю; середній - у медсестер хірургічного профілю; низький -у медсестер терапевтичного профілю.

Висновок. Медичні працівники з високим і середнім рівнем емоційного інтелекту мають низький рівень прояву симптомів емоційного вигорання (незадоволеності собою; відчуття загнаності в клітку; тривоги і депресії; редукції професійних обов'язків; емоційного дефіциту; особистісної відстороненості; психосоматичних і психовегетативних порушень), а також низький рівень розвитку фаз напруги, резистенції, виснаження, деперсоналізації і редукції особистісних досягнень.

Ключові слова: стрес, емоційне вигорання, симптоми емоційного вигорання, емоційний інтелект, медичні працівники. 


\title{
Резюме
}

\section{АНАЛИЗ ВЗАИМОСВЯЗЕЙ ОСОБЕННОСТЕЙ ЭМОЦИОНАЛЬНОГО ВЫГОРАНИЯ И ПОКАЗАТЕЛЕЙ ЭМОЦИОНАЛЬНОГО ИНТЕЛЛЕКТА У МЕДИЦИНСКИХ РАБОТНИКОВ}

\author{
Н. Г. Пилипенко, О. А. Сидоренко
}

Государственное научное учреждение «Научно-практический центр профилактической и клинической медицины» Государственного управления делами, г. Киев, Украина

Цель работы - представлить результаты статистического анализа взаимосвязей особенностей эмоционального выгорания и показателей эмоционального интеллекта у медицинских работников.

Материалы и методы - в исследовании приняло участие 4 группы респондентов (110 медицинских работников): врачи хирургического профиля, врачи терапевтического профиля, медсестры хирургического профиля, медсестры терапевтического профиля. Оценка особенностей эмоционального выгорания и эмоционального интеллекта проводилась с помощью диагностических методик эмоционального выгорания (В.В. Бойко), опросника эмоционального выгорания К. Маслач и С. Ажексон (адаптация Н. Водопьяновой) и методики эмоционального интеллекта (Н. ХолА). Исследование состояло из двух этапов. Целью первого этапа было определение уровня и особенностей проявления эмоционального выгорания медицинских работников по следующим симптомам: (эмоциональное истощение; деперсонализация; редукция личностных достижений; «напряжение» (переживание психотравмирующих обстоятельств, неудовлетворенность собой, загнанность в клетку, тревога и депрессия); “резистенция» (неалекватное избирательное эмоциональное реагирование, эмоционально-моральная дезориентация, расширение сферы экономии эмоций, редукция профессиональных обязанностей); «истощение» (эмоциональный дефицит, эмоциональная отстраненность, психосоматические и психовегетативные нарушения). Также была произведена оценка уровня проявления эмоционального интеллекта медицинских работников по следующим показателям: эмоциональная осведомленность, управление эмоциями, самомотивация, эмпатия, распознавание эмоций других людей. Второй этап исследования был направлен на определение особенностей взаимосвязи отдельных показателей эмоционального выгорания с отдельными показателями эмоционального интеллекта медицинских работников. Математическую обработку результатов исследования проводили с использованием коэффициента корреляции Спирмена средствами компьютерной программы SPSS 17.

Результат исследования и их обсуждение. Результаты нашего исследования показали, что: 1) у преобладающего болышинства испытуемых наблюдается высокий и средний уровни редукции личностных достижений, а также сформирована или находится в стадии формирования такая фаза эмоционального выгорания, как «резистенция» (неадекватное избирательное эмоциональное реагирование, эмоционально-моральная дезориентация, расширение сферы экономии эмоций, редукция профессиональных обязанностей); 2) у половины испытуемых наблюдается высокий и средний уровни эмоционального истощения, деперсонализации; 3) у четверти респондентов сформирована такая фаза эмоционального выгорания, как «истощение» (эмоциональный дефицит, эмоциональная и личностная отстраненность, психосоматические и психовегетативные нарушения). Выявлены такие уровни развития эмоционального интеллекта у разных групп медицинских работников: а) высокий и средний - у врачей хирургического профиля и врачей терапевтического профиля; средний - у медсестер хирургического профиля; низкий - у медсестер терапевтического профиля.

Вывод. Медицинские работники с высоким и средним уровнем эмоционального интеллекта имеют низкий уровень проявления симптомов эмоционального выгорания (неудовлетворенности собой; ощущения загнанности в клетку; тревоги и депрессии; редукции профессиональных обязанностей; эмоционального дефицита; личностной отстраненности; психосоматических и психовегетативных нарушений), а также низкий уровень развития фаз напряжения, резистенции, истощения, деперсонализации и редукции личностных достижений.

Ключевъе слова: стресс, эмоциональное выгорание, симптомы эмоционального выгорания, эмоциональный интеллект, медицинские работники.

Інформація про авторів знаходиться на сайті http://www.cp-medical.com.

Дата надходження до редакції - 7.10.2021 p. 